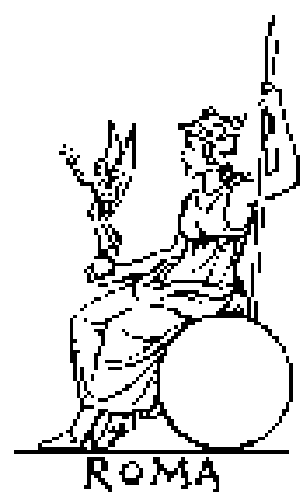

The Transpadane Question and the Alien Act of 65 or 64 B.C.

Author(s): E. G. Hardy

Source: The Journal of Roman Studies, Vol. 6 (1916), pp. 63-82

Published by: Society for the Promotion of Roman Studies

Stable URL: http://www.jstor.org/stable/296267

Accessed: 15/06/2014 08:43

Your use of the JSTOR archive indicates your acceptance of the Terms \& Conditions of Use, available at http://www.jstor.org/page/info/about/policies/terms.jsp

JSTOR is a not-for-profit service that helps scholars, researchers, and students discover, use, and build upon a wide range of content in a trusted digital archive. We use information technology and tools to increase productivity and facilitate new forms of scholarship. For more information about JSTOR, please contact support@ jstor.org. 


\section{THE TRANSPADANE QUESTION AND THE ALIEN ACT OF 65 OR 64 B.C.}

By E. G. HARDY.

In the course of an article in this fournal (vol. iii, part I, pp. 70 and 86) I had occasion to criticise the interpretation given by Mr. J. M. Nap to an important passage of Dio Cassius (xxxvii, 9) in connexion with a dispute between the censors of 65 on the subject of the Transpadani, and a subsequent Alien Act passed by a tribune named Papius. Not having his own article, which is written in Dutch, ${ }^{1}$ accessible, I had gathered his views from the paper of a not unfriendly critic in a French review, and I only dealt with them incidentally as bearing upon the date assigned by him to the so-called lex Iulia Municipalis. Since then, Mr. Nap has pointed out to me that, at least in one particular, I had misapprehended his meaning; he has also very kindly sent me a copy of his article, and has developed and elucidated his views in several letters. I have in consequence carefully re-studied the statements of Dio and I propose to examine somewhat more in detail Nap's interpretation and hypotheses, and at the same time to set forth by their side my own reconstruction of the situation, as far as the Transpadani and the Alien Act are concerned.

It will be convenient at the outset to cite in full the passage to be examined. After describing the portents and rumours of conspiracy which marked the year 65, Dio (loc. cit.) goes on :

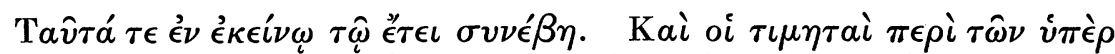

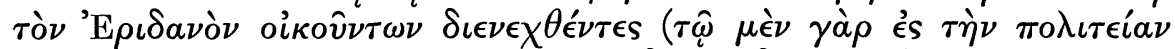

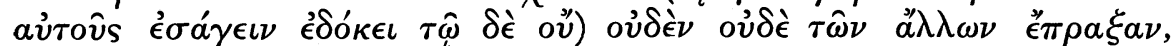

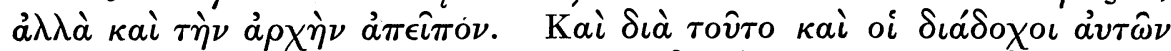

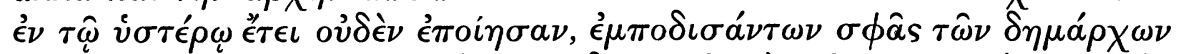

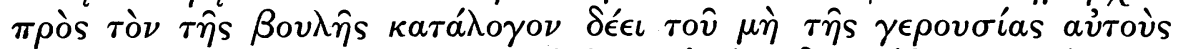

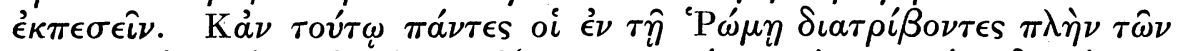
$\tau \grave{\eta े \nu ~ \nu \nu ิ \nu . ~ ' I \tau a \lambda i ́ a \nu ~ o i k o v ́ v \tau \omega \nu ~ \epsilon ́ \xi \epsilon ́ t \pi \epsilon \sigma o \nu ~ T a i ́ o v ~ \tau \iota \nu o ̀ s ~ \Pi a \pi i ́ o v ~ \delta \eta \mu a ́ p \chi o v ~}$

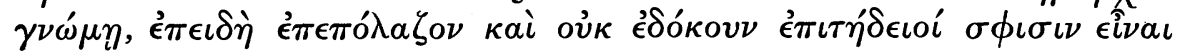

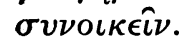

I. THE POLITICAL AND JURISTIC POSITION OF THE TRANSPADANI.

Nap's first point is that the term 'Transpadani' in this, as in other passages of our authorities, is used loosely to cover all the

\footnotetext{
1 Dateering en Rechtskarakter der Z.-G. lex
} Iulia Municipalis. Verhandelingen der koninklijke

Akademie van Wetenschappen te Amsterdam Deel xi, no. iv. 
inhabitants of Gallia Cisalpina; that the Transpadani and the Cispadani were in precisely the same legal and juristic position; and that the questions at issue in 65 properly concerned the Cisaipini as a whole, and not the Transpadani alone. While specifying no other passage in which this confusion may be detected, he rests his contention on two grounds. (I) He argues that the so-called lex Rubria, instead of belonging to the Caesarian period, was the 'lex provinciae' of Cisalpine Gaul, being the original 'lex data' framed by Sulla, when he established the province. But, as the law treats all communities north and south of the Po on the same juristic principles, there could have been no difference of status between different parts of the province. ${ }^{1}$

I have dealt in detail with Nap's arguments as to the nature and date of this law in the English Historical Review, July, r9i6. They rest largely on the internal and doubtful evidence of legal procedure, but partly on what seem to me unsupported and improbable hypotheses. I will only remark here (a) that from the contents of the extant chapters, as well as from the titles of magistrates compared with those on the Table of Heraclea, the uniformity of status throughout the province would seem to find its best explanation in the possession by all the communities of the Roman civitas; while at the very least they must all, when the law was passed, have been 'fundi' of Roman law. Neither, however, of these two conditions can be assumed earlier than 49 B.c. (b) The remaining fragments are very different from what we should expect to find in the 'lex data' of a newly constituted province. As a matter of fact, an examination of the condition of Cisalpine Gaul in Sulla's day makes the uniformity of status, unwisely insisted on by Nap as implied by the law, one of the strongest arguments against his hypothesis as to its date. (2) This becomes more apparent when we come to Nap's second reason for believing in an identity of legal position between Transpadani and Cispadani. He relies upon a statement made by Mommsen, ${ }^{2}$ taken, I must observe, out of its context, to the effect that very probably the lex Pompeia conferred the 'ius Latii' collectively on all the 'civitates foederatae' of Gallia Cisalpina. But, Mommsen goes on to observe, since north of the Po a considerable number of 'civitates foederatae' were affected by the measure, while south of the river Ravenna perhaps stood alone, the operation of the law has been erroneously limited to the Transpadane region. The difference, however, between the two parts of the province was really political rather than juristic.

I quite accept Mommsen's assumption that the lex Pompeia treated alike all 'civitates foederatae' within the area of Cisalpine

\footnotetext{
${ }^{1}$ Het iudicium legitimum in de Romeinsche wetgeving. Overgedrukt uit Themis, 1912, pp. I83 I.
}

2 Furist. Scbriften, i, 183 . 
Gaul, and I believe that it also treated alike, probably on lines already laid down by the lex Iulia of the previous year, all Latin colonies within the same area, in other words that it made them all Roman communities. But, if this is granted, the juristic identity between the Transpadane and Cispadane regions, on which Nap insists, will merely mean that certain categories of towns were treated in the same way in both. On the other hand, the political difference, which after all was the important factor, stands out in sharp relief. In the Cispadane region there were (a) such already existing Roman colonies as Mutina and Parma; (b) the Latin colonies of Placentia, Bononia and Ariminum (see below) now made Roman; and (c) a considerable number of fora, which Mommsen (loc. cit.) must be right in regarding as settlements of Roman citizens, though not strictly urban communities. It follows that, with the possible exception of Ravenna, the Cispadani after 89 were practically all Roman citizens. It was of course in reference to these Roman communities south of the Po that Cicero wrote in 65 : 'videtur in suffragiis multum posse Gallia.' 1 On the other hand, in the much larger area north of the Po, with the exception of two colonies, Dertona and Eporedia, already in Mommsen's opinion Roman, and two others, Cremona and Aquileia, made Roman by the lex Pompeia, the Transpadane communities were towns possessing only the 'ius Latii.' Under such conditions, where are we to find the identity of legal status throughout the province for which Nap contends? Is it not manifest that the political and legal questions still requiring solution after 89 would be, as all our authorities represent them, Transpadane and not Cisalpine questions?

\section{THE LEX POMPEIA AS THE LEX PROVINCIAE OF GALLIA CISALPINA.}

If we accept Mommsen's hypothesis that the operation of the lex Pompeia was not confined to the Transpadane country, but affected also what we know as the Cispadane portion of the province, I think we are bound to explain how it came to do so. On Mommsen's view, usually accepted, the province was not in existence till Sulla created it in 82 or $8 \mathrm{I}$. When it was created, it was of course necessary that some definite dividing line, whether the Aesis or the Rubicon, should be fixed as the boundary between Italy and the province. But why, on this view, should this or any dividing line have been selected in 89 to distinguish the spheres within which the lex Iulia and the lex Pompeia should operate? It is true that the population immediately south of the Po had originally been largely or mainly Celtic, and even that the country as far down

1 ad Att.i, $\mathbf{x}, 2$. 
as Ariminum was known as 'ager Gallicus.' But though this racial distinction was long recognised, and marked by a line running from the Arnus on the west to the Aesis on the east, and in spite of a difficult passage of Livy, in which Ariminum is spoken of as a ' provincia' allotted to a praetor late in the third century в.c. (Liv. 2 ', 44), it is certain that there was no administrative distinction between Italy and the 'ager Gallicus,' and that, in fact, the whole peninsula up to the Alps was regarded as Italy. ${ }^{1}$ The whole country, like the rest of Italy, was under the general direction of the consuls; colonies, both Roman and Latin, were founded in it in considerable numbers, and most of its other towns became members of the Italian confederacy. No doubt the Transpadane region was still thoroughly Celtic, and conditions north of the river were in many ways essentially different from those in the south. But between those in the Cispadane part of the 'ager Gallicus' and those in Etruria and Umbria there was practically no difference at all.

Now these being the conditions in 90 and 89 , it is intelligible that the government would think it well to treat north Italy in a different way from the rest of the peninsula, and therefore not to apply to it the operation of the lex Iulia, which would have meant the elevation of all its towns to the status of Roman 'municipia.' Hence the advisability of a separate law, the lex Pompeia; but unless some drastic change of administration was contemplated, the obvious dividing line between the operation of the two laws was the Po, marking a concrete difference of conditions, and not the old Arnus-Aesis line, marking a nearly obsolete racial distinction. This, however, according to Mommsen, was not the course adopted, for the lex Pompeia changed the status of all 'civitates foederatae' within the area of the old 'ager Gallicus.' The position is not made easier by Mommsen's inference from the words of Aulus Gellius $(3,4,3)$, ' universo Latio lege Iulia civitas data est,' that Aquileia, Cremona, Placentia and Bononia received the civitas from the latter law, so that both laws operated in the Transpadane and Cispadane regions, though affecting different classes of towns.

I believe that we may escape from these difficulties and gain a more reasonable view of the policy adopted after the Social war if we discard the hypothesis that Cisalpine Gaul was made a province by Sulla, and place its creation in 90-89. It is notorious that no ancient writer assigns its establishment to Sulla. The only passage where his name is coupled with the province is a fragment of Licinianus (ed. Teubn. p. 32) referring to a date some years before the dictatorship: 'data erat et Sullae provincia Gallia Cisalpina.' I do not pretend to explain the statement, but it seems almost to imply the existence of the province some years earlier than Mommsen's

\footnotetext{
1 See Liv. 39, 54, and Polyb. ii, 14.
} 
hypothesis assumes. At any rate, whatever the statement means, we may safely reject the inference drawn from it by Nap, who believes that the province was ' given ' to Sulla, while dictator, for the purpose of receiving a 'lex data,' and heroically calls in the lex Rubria to fill the part. But while that law is conspicuously inappropriate to the known conditions of the country at the time, what we know of the details of the lex Pompeia corresponds exactly with what we should expect to find in a 'lex provinciae,' settling the political and juristic relations within a newly created province.

The enfranchisement of Italy meant the disappearance of the Italian confederacy, and if, for perhaps sufficient reasons, the government declined to include in the new arrangement the purely Celtic and non-Romanised region in the north, some other substitute for a military confederacy, now out of date, would have to be provided. In view of the constant danger from Alpine tribes, a danger recognised by the settlement of military colonists at Comum by Pompeius, ${ }^{1}$ the immediate conversion of the country into an armed province was an obvious course. The emergency arose at once, when the league ceased to exist, and would surely have been met at once, and not have been left for Sulla to deal with after an interval of eight or nine years.

Whoever were the statesmen responsible for the settlement after the Social war, it was admirably adapted to the situation, and I believe that the establishment of a Cisalpine province was an essential part of it. But the lex Iulia admitted of no delay, and while the claims of the 'civitates foederatae' would have to be considered separately, it was essential to give the civitas at once en bloc to all Latin colonies, it being impossible to make a distinction between those in Italy and those which were henceforth to be provincial towns; hence the 'universo Latio'. of Gellius. But when in the following year effect was given to the scheme of creating a Cisalpine province by the lex Pompeia, this grant of citizenship to the Latin colonies was naturally confirmed, or rather taken over by the provincial law. In this way we escape the difficulty involved in Mommsen's view that within the same area one law dealt with the Latin colonies, another with the 'civitates foederatae.' That the lex Pompeia conferred the 'ius Latii' on the Transpadane towns we know very precisely from Asconius, ${ }^{2}$ and this fixing of graduated status is exactly what a 'lex provinciae' would effect. Equally appropriate to such a law was the arrangement, testified to by Pliny, ${ }^{3}$ of ' attributing' native tribes to the urban communities, an arrangement which also implies another characteristic of a provincial law, viz. the delimitation of municipal and colonial territories. Moreover, 
it is now possible to understand what Mommsen's dating of the province leaves unexplained, why the operation of the law extended south of the Po. For whenever a province of Cisalpine Gaul came into existence, it was bound by its very name to include all that the 'ager Gallicus' had once included. It is true that the southern portion would remain, as far as political status was concerned, 'Italia verius quam provincia'; but this was perhaps no disadvantage, as furnishing a useful administrative background to the new province, as well as a type to be gradually attained by the rest. If the con siderations which I have put forward have weight, it follows almost of necessity that the original boundary of the province was the old Arnus-Aesis line. Later on, as we know from Strabo ${ }^{\mathbf{1}}$ and the incidents of Caesar's time, it was the Varus on the west and the Rubicon on the east. We may accept Mommsen's hypothesis that it was Sulla who made the change, and that his claim to extend the 'pomerium'2 was based on the consequent extension of Italian soil. I would note, however, that Mommsen vitiates his own hypothesis by making this extension coincide with the creation of the province, which was in itself a limitation and not an extension of Italy.

\section{THE TRANSPADANI AS LATINS WITH THE ' LATER LATINITAS.'}

Suetonius speaks of the Transpadane towns as ' coloniae Latinae,' and we learn from Asconius ${ }^{3}$ how this term is to be understood. ' Pompeius enim non novis colonis eas (Transpadanas) colonias constituit, sed veteribus incolis manentibus ius dedit Latii, ut possent habere ius quod ceterae Latinae coloniae, ut petendo magistratus civitatem Romanam adipiscerentur.' 'The 'Transpadani therefore possessed the 'later Latinitas,' the distinguishing mark of which is noted by Asconius; but ' the other colonies' possessing it are not specified. Nap agrees with Beloch ${ }^{4}$ that they were the 'duodecim Latinae coloniae quae Q. Fabio et Q. Fulvio consulibus (209 B.c.) abnuissent milites dare' 5 ; but these colonies were : Circeii (393), Suessa and Cora (?) Ardea (4r2), Sutrium (383), Nepete (383), Setia (382), Cales (334), Interamna (312), Alba (303), Narnia (299), Carseoli (298), ${ }^{6}$ and therefore all of more or less early foundation. But (I) we should expect to find the 'later Latinitas' in the latest Latin foundations; and (2) I fully agree with Mr. Strachan-Davidson ${ }^{7}$

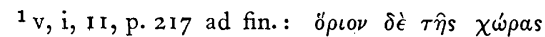

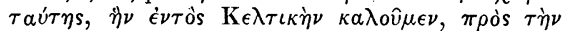

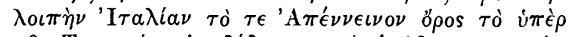

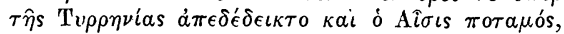

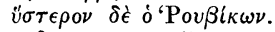

2 Tac. Ann. xii, 23, and Sen. de brev. vit. I3.

3 in Pison. 3.
}

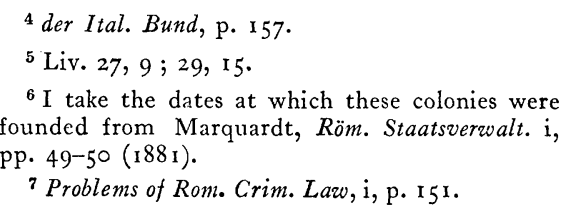


that, if the magistrates of these Latin colonies, who play a prominent part in the affair of 209, had had the right alluded to by Asconius, Livy must have mentioned it. As a matter of fact twelve Latin colonies were founded later than any of the foregoing towards the end of the third and the beginning of the second century, B.c. Ariminum (268) being the earliest, and Aquileia (I8I) the latest; and of these no fewer than four, Ariminum, Placentia, Bononia and Aquileia, were within the limits of the 'ager Gallicus.' It seems to me beyond a doubt that Mommsen is right in identifying these with the 'duodecim coloniae' alluded to by Cicero in pro Caecin. 35, I02, and explicitly associated by him with Ariminum, and that it is in these later foundations that the ' later Latinitas' resided. ${ }^{1}$

Nap, however, refuses to accept this view, contending that the existence of two separate groups, known as the 'duodecim coloniae' is incredible, while he gives his own interpretation to the passage in pro Caecin. In reply to the objection that Caecina, as a citizen of Volaterrae, a town disenfranchised by Sulla, could not claim an inheritance by Roman law, Cicero says : 'Sulla ipse ita tulit de civitate ut non sustulerit horum nexa et hereditates. Iubet enim eodem iure esse quo fuerint Ariminenses; quos quis ignorat duodecim coloniarum fuisse, et a civibus Romanis hereditates capere potuisse ?' It is not disputed that Ariminum is cited as having been a Latin colony possessing the 'ius commercii'; but Nap argues that the 'duodecim coloniae' are those spoken of by Livy, and that Ariminum is cited, not as one of them (which of course it was not) but as having been put in their juristic position. But (a) Ariminum is clearly taken as the type of a class, and therefore far more likely to be the first and most conspicuous instance of a new class than a mere annexe to a well-known and long-established group. (b) The phrase 'duodecim coloniarum fuisse' has no meaning unless Ariminum was actually included under 'the twelve,' and as it was certainly not one of Livy's list, it must have belonged to another group. Nor is there any point in Nap's repudiation of two separate groups of ' twelve colonies,' for there is not the smallest necessity to assume the existence of more than one. A reference to Livy's narrative and a glance at the list of 28 Latin colonies founded before Ariminum will show that Livy's 'duodecim coloniae Latinae' is a distributive and not a collective expression and that they were merely the colonies, happening to be twelve, which took the common action in 209, but were in no other way marked out from the other fifteen.

We may therefore assume that the Latin colonies taken by Pompeius as his model were the Ariminum-Aquileia group, possessing the later ' ius Latii.' 


\section{THE MILITARY SERVICE OF THE TRANSPADANI.}

Up to the Social war and as long as the Italian confederacy existed we know that the Latin communities and the 'civitates foederatae' had to furnish soldiers ' ex formula togatorum,' i.e. in accordance with a military register, drawn up in each and sent to Rome. ${ }^{1}$ It was indeed in connexion with this requisition of soldiers that the trouble arose in 209 with Livy's twelve Latin colonies. But after the Social war the Italian confederacy ceased to exist, while by the operation" of the lex Iulia and lex Pompeia there were no more ' civitates foederatae,' and the only Latin towns were the new Transpadane colonies, which were without the military substratum hitherto essential in colonies. It is therefore a question whether and in what form the burden of military service was imposed upon the Transpadani in the following period. Nap appears to hold that the conferment of Latin rights and inscription on the "formula togatorum' involved one another; that Pompeius accordingly inscribed the Transpadane colonies on the 'formula,' but that, when the country became a province, a difficulty arose, the position of the Transpadani, or as he prefers it, of the Cisalpini, became the subject of dispute, and a settlement by means of legislation was in the air. For this view I can see no evidence whatever, though it is no doubt true that inscription on the 'formula'. was properly intended for Italy for the simple reason that the confederacy was a purely Italian confederacy. (i) In the first place, the words of the lex agraria, where alone the 'formula togatorum' is mentioned, show that it was no more associated with Latin communities than with the other ' socii' or ' civitates foederatae.' It was in fact an essential detail of the Italian confederacy, and inscription on the 'formula' was in no sense a political privilege, but a military burden. (ii) In the second place, the difficulty involved in the supposed inscription of the Transpadani on the 'formula' by Pompeius would not have arisen from the creation of the province, but from the fact that the military confederacy, which alone had given meaning to the 'formula togatorum,' had ceased to exist. So far from admitting that conferment of 'Latinitas' and inscription on the 'formula' were equivalent to one another, I am inclined to affirm that they belonged to two entirely different military and political systems.

As long as Rome was the head of a military league, the raison d'être both of 'civitates foederatae' and of Latin colonies was to discharge their league obligations, while enjoying a guaranteed internal autonomy. When, as an example, 6,000 colonists were sent

${ }^{1} \mathrm{cf}$. lex agrar. 21 : 'sociumve nominisve Latini quibus in terra Italia ex formula togatorum milites inperare solent.' 
to Placentia to act as a 'propugnaculum imperii,' exchanging their Roman status for the rights of Latins, it would have been a misuse of terms to describe the proceeding as the conferment of the 'ius Latii' upon Placentia, just as the conclusion of a 'foedus' with some Italian town did not imply the conferment on that town of any special honour or privilege. In both cases, however, inscription on the 'formula togatorum' would be a compulsory concomitant of the step. On the other hand, when the Italian league was replaced by an enfranchised Italy, Latin communities and 'civitates foederatae' alike, if they survived at all, could find no place except in the provinces. This was what happened, but the meaning both of 'Latinitas' and of 'federate' status was changed. It is from this time that it becomes correct to say that they were conferred, and conferred as a reward, or a mark of distinction or political privilege. With regard to the 'ius Latii,' this comes out clearly in the action of Pompeius, as described by Asconius. The Transpadani, without receiving military colonists or undertaking military obligations, were promoted to a higher grade of juristic and political status, intended probably to be preparatory to complete absorption in the citizen body. It was precisely the course adopted afterwards by Caesar in Narbonensis and elsewhere, and which reached its climax when Vespasian conferred the 'ius Latii' on all non-privileged towns in Spain.

I hope I have shown that the 'formula togatorum' was out of date and out of place when Pompeius constituted, as I believe he did, the province of Cisalpine Gaul. But the inhabitants, and not least those of the non-Roman Transpadane portion, were excellent material for soldiers, and they must have been somehow utilised. As a matter of fact, a passage in Caesar's commentary on the civil war (iii, 87) proves that they were. In 48 в.c. Labienus speaks of Caesar's forces in Epirus as largely made up from recent levies in Gallia citerior, and specifies ' $p l e r i q u e$ ex Transpadanis coloniis.' The implication certainly is that these men were legionaries, and this creates a difficulty, for it is certain that Latins were not eligible for the legions, and, now that there were no 'cohortes sociorum' in the old sense, would serve among the 'auxilia.' ${ }^{1}$ How the Latin citizens in the numerous Latin towns under the Principate were made subject to military service I confess I do not know, and the two fragmentary charters of Salpensa and Malaca throw no light on the subject. But with regard to the question in Gallia Cisalpina, we must remember that the practice of reinforcing the Roman army from the provinces was still in its infancy, and though there was no difficulty in getting legionaries from the numerous colonies in the south, the arrangements for recruiting Transpadani

\footnotetext{
1 cf. the phrase 'Transpadani alarii' in Cic. ad Fam. ii, 17, 7.
} 
were probably vague and largely dependent on the discretion of the proconsul. Still, I would suggest three considerations which may help to explain the statement of Labienus: (a) the number of Roman citizens in the Transpadane colonies had been yearly increasing between 89 and 48 by the continuous enfranchisement of magistrates and their families, so that there would in this way have been a considerable body of persons in each Latin town available for legionary service; (b) more than a year before the date of Labienus' speech the lex Roscia had been passed, enfranchising all the Transpadane colonies, so that in all levies held in the last nine months of 49 Transpadani could have been enlisted in the legions; (c) it is highly probable that Caesar, with or without legal authorisation, may have anticipated the practice, very common in the period of the civil wars, of recruiting ' peregrini,' but giving them the 'civitas' on enlistment. It is possible even that Pompey caused the same thing to be done by his legates in Spain, since a comparison of Bell. Civ. i, 85, 6, with ii, 20, 4, shows that a 'legio vernacula' (the name given to legions containing such soldiers) under Varro had been recently raised in the Further province.

\section{THE TRANSPADANE QUESTION IN 65 .}

It appears therefore that the Transpadane towns after the creation of the province were not only treated differently from the towns of Italy, which, either at once or gradually, were enfranchised by the operation of the lex Iulia, but found themselves in an inferior political status to that of practically all the Cispadane communities, and even of a few colonies north of the Po. Of their inhabitants some were Roman citizens, and the number of these was slowly increasing with every year, but the majority were politically and juristically Latins, possessing indeed the 'ius commercii,' but probably without the 'ius conubii,' and certainly lacking the 'ius suffragii' and the 'ius honorum.' In these circumstances there was bound to be a Transpadane question. The Latin colonies were certain sooner or later to put forward a claim to full citizen right, and some section of politicians in Rome was sure from interested or disinterested motives to support their claim. This was precisely the situation in 67, as revealed by Suetonius (Iul. 8). The Latin colonies were then 'de civitate Romana agitantes,' and clearly receive some sort of encouragement from Caesar. One would have thought the phrase of Suetonius sufficiently explicit, but Nap, with what I can only call a perverse ingenuity, represents the agitation as due to difficulties experienced by these Latins in exercising the old Latin right of voting, when in Rome, in one of the tribes. He believes that this grievance must have been rectified before 65 , because in 
that year Cicero writes : 'videtur in suffragiis multum posse Gallia.' 1 It seems hardly necessary to point out that the two passages are wholly out of relation to one another, for Cicero is referring to the Roman communities of the province which he thought of canvassing.

Next we come to Dio's statement about the year 65, showing that the agitation of 67 was now affecting party struggles in Rome. We know from Plutarch that Crassus and Lutatius Catulus were censors in 65 , and Dio without giving names, says that the censors were hopelessly at variance on the question of admitting the Trans-

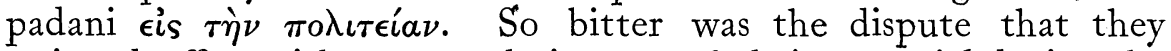
resigned office without completing any of their censorial duties, the ' lectio senatus,' the census or the business of state contracts. The difficulty is to explain the locus standi of the censors in deciding this question of Transpadane enfranchisement, which Crassus, as we should expect from his close association at this time with Caesar, favoured, and Catulus in the interest of the optimates opposed.

It is obviously not a sufficient explanation to say that the inclusion or non-inclusion of the Transpadani in the register of the Roman census was the point at issue, for the census lists could only include Roman citizens, and the Transpadani were not yet brought eis $\tau \grave{\eta} \nu \pi o \lambda \iota \tau \epsilon i a \nu$. Mommsen sought to evade the difficulty by representing Crassus as trying by the enrolment of the Transpadani on the burgess register to give effect to the 'standpoint of the popular party' that they were already legally entitled to the franchise, and needed no further act of legislation. ${ }^{2}$ In this case Dio must have

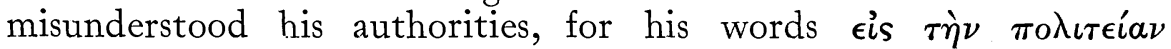
$\dot{\epsilon} \sigma a ́ \gamma \epsilon \iota \nu$ imply that they were still excluded from the civitas. But how could the Transpadani be legally entitled to the franchise unless some law had granted it? But there is no trace whatever of any such law, whereas Mommsen himself accepts the evidence of Asconius as to the Latin rights conferred by the lex Pompeia. But surely Mommsen's case is effectually put out of court by the fact that in 49 Caesar, in spite of this standpoint of the popular party, thought it necessary to confer the franchise on the Transpadani by an act of legislation. ${ }^{3}$

\footnotetext{
1 ad Att. i, I, 2.

${ }^{2}$ Rom. Hist. Engl. trans. iv, p. ${ }_{5} 58$. One would have hoped that this ill-considered view would have been modified in later works, but it is reasserted in a comparatively late article: 'es nahmen die Caesarianer an, dass die Transpadaner das Bürgerrecht bereits besassen.' (Furistiscbe Scbriften, i, p. 18 I.)

${ }^{3}$ Dio (xli. 36) places the grant in 49 ; кai rois

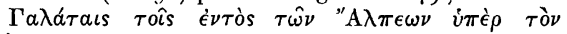

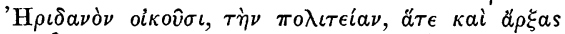

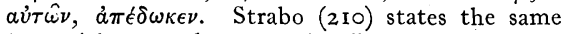
fact without a date, but implies a long interval between it and the enfranchisement of Italy:

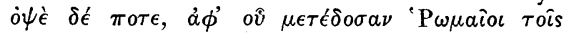

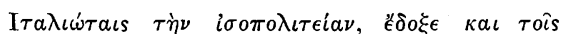

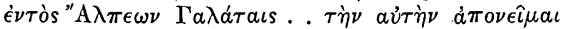

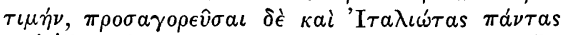
кai' 'Pwuaious. The law, as we know from the Atestine Fragment, was passed by L. Roscius, praetor in 49, on I ith March. I notice that Nap, applying his own canons of internal probability, regards the lex Roscia as granting to Caesar full powers to make and unmake laws, and as annexing Gallia Cisalpina to Italy. The latter point seems a misunderstanding of Strabo's statement, which records, not very clearly, two separate events. Italy was extended to the Alps, as we know from Dio (xlviii, I2) in $4 \mathrm{I}$. As to Nap's other assertion we may await his evidence for it. 
We must therefore find some other clue to the situation in which the censors of 65 figure so prominently. Mr. Nap supplies us with a new one. Considering his repeated insistence that the point at issue was the inclusion or non-inclusion of the Cisalpini as a whole, and not of Transpadani alone, and that the latter.were in the same legal position as the Cispadani, I hardly wonder at M. Besnier's inference that in Nap's opinion the Transpadani were already Roman citizens. At any rate, the inference is not correct, for Nap admits them to have been still Latins with the rights of the 'duodecim coloniae,' as he understands that term. But there was nevertheless a party in Rome in 65 which advocated their inscription on the Roman census list. This inscription, he argues, would not have implied that the Cisalpini were Roman citizens; on the contrary if Crassus had had his way, they would have been enrolled, not on the ground that they were Roman citizens, but on the ground that they were men capable of serving in the Roman legions as if they were Roman citizens. The last six words give the case away, for they imply, what it is surely unnecessary in these days to establish, that the privilege or burden of legionary service belonged exclusively to Roman citizens. It is enough to take Nap's own instance. He declares that the senate ordered the recalcitrant Latin colonies in 209 to be included in the Roman census. A reference to Livy (29, I 5) shows that on the contrary each colony was ordered to take its own census in accordance with a 'formula,' i.e. scheme of tabulated schedules, supplied by the Roman censors. The whole affair indeed related to the 'formula togatorum,' which had nothing to do with the legions, and nothing to do with the Roman census or the Roman censors, though the latter might supply the 'formula' (in the sense given above) to be used. This confusion about legionary service vitiates Nap's explanation, while it is open to the same objection as Mommsen's, that, as long as they were non-citizens, the Transpadani could not possibly be enrolled in the census either for military or political objects. I may add that Nap's explanation of the dispute as one merely concerned with the military service of the Transpadani,

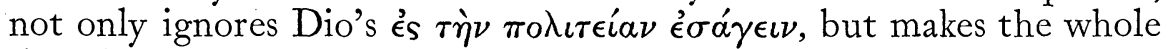
situation unintelligible, for it represents Crassus as wishing to impose a military burden on Caesar's protégés, not to confer a political privilege. ${ }^{1}$

I am convinced that the only satisfactory way of explaining the attitude of the censors in 65 , without riding rough-shod over Dio, and in accordance with the known situation, is to assume Caesar's intention of marking the year by the enfranchisement of the Transpadani. He had given encouragement to their claims in 67; he

\footnotetext{
1 This is clear from the supposed inclusion in the Roman census of the Latin colonies in 2og, which was the result of disobedience.
} 
had, according to an historian cited by Suetonius, ${ }^{\mathbf{1}}$ intrigued with them at the beginning of this very year; and their enfranchisement might greatly further his own plans and those of Crassus in the immediate future. For we may take it as highly probable that they had already determined to make the consular and tribunician elections in 64 a trial of strength. If Cicero hoped much from the votes of Cispadane Gaul, ${ }^{2}$ how much more important would be the more numerous Transpadane towns if they could be enfranchised in time?

Caesar certainly had some following in the tribunician college, for he tried 'per partem tribunorum' to get a command in Egypt, and I believe that a law to enfranchise the Transpadani was to have been part of the year's programme. This is not a mere conjecture in the air, but the only means of explaining the irreconcilable opposition of the censors on the question of the Transpadane citizenship. For the censors had no locus standi in the matter till the time came for the enrolment of the new citizens in the burgess lists, and this could only be when an enfranchising law had qualified them for such enrolment. As the law was not passed, the practical question never came before the censors, who indeed could not have touched even their preliminary function of a 'lectio senatus,' since we find it attempted by the censors of the following year. (cf. also ovंdèv

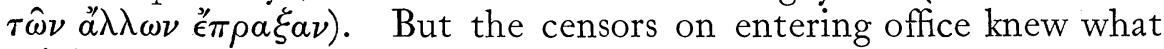
might come, and they represented irreconcilable views. Crassus might have declared that, unless opposition to the measure was withdrawn, he would block every censorial act; or Catulus might have threatened to make the law inoperative, at any rate for the moment, by refusing his co-operation in the enrolment in tribes and centuries. Under such circumstances their resignation was inevitable, and owing to that, and the energetic action of the optimates this year, the law was not proposed.

\section{THE CENSORS OF 64 .}

I again have to join issue with Mr. Nap. He declares that if, after the fiasco of 65 , censors were again created in 64 , it must have been because the cause of dispute had been in the interval settled definitely one way or the other. To have created fresh censors merely to be driven to the same dead-lock was, he argues, inconsistent with Roman

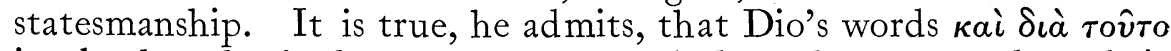
imply that the fresh censors were wrecked on the same rock as their predecessors, viz. the Transpadane question, but for the reasons given he must be mistaken.

In what way then was this Transpadane, or, as Nap will have it,

1 Iul. I I.

2ad.At! i, I, 2. 
Cisalpine question settled after the resignation of the censors in 65 and before the creation of the next pair in 64 ? He finds the settlement in a lex Papia, which is preserved on the Table of Heraclea in lines 143 to 159 . This law, by providing that in future a Roman census should be accompanied by a census in all 'municipia,' 'coloniae' and 'praefecturae' within Italy, implicitly excluded from the Roman census the Cisalpini or Transpadani because they were not within but outside Italy, and therefore cleared away all difficulties on this score from the path of the new censors. Now Nap does not pretend that there is any reason for connecting this law with Papius or the year 65 except that it meets the situation. But does it? The 'municipia,' 'coloniae' and 'praefecturae' within Italy were all fully enfranchised towns, and the law explicitly orders a census of the Roman citizens in those towns. It is true that this excludes the Transpadani, but it only excludes them in the sense that it has nothing to do with the Transpadane question; it only excludes them as it excludes the towns of Sicily or of Africa. The words ' in Italia'? have no doubt a limiting force, for they rule out all 'municipia,' 'coloniae' and 'praefecturae' of Roman citizens outside Italy, which in the year 65 would have meant the Cispadane colonies and the four colonies north of the Po. But this would clearly not have helped the censors of 64, whose difficulty, on Nap's own showing, was the enrolment of men who, though not Roman citizens, might, if enrolled, be capable of serving in the legions. As a matter of fact, no law was required to exclude non-citizens; they were excluded by the very nature of the census; while on the other hand, if an enfranchising law was once passed, nothing could legally prevent their enrolment, though the temporary obstruction of particular censors might delay it. The supposed lex Papia therefore did not settle the question between the censors, for it was as completely out of relation to it as Nap himself makes the other two leges Papiae which he declares to have been passed on the same day. ${ }^{1}$

Nor do I see the force of the argument that new censors would not have been created till the dispute between the former ones had been settled by legislation. For it did not follow that the next censors would also hold opposite views on the. matter, and each

1 The three leges Papiae are (I) the Alien Act, mentioned by Dio, of which we have the conclusion in lines I to I9 of the Table of Heraclea, and of which Nap's interpretation will be discussed below; (2) a law dealing with aedilician duties, also on the Table; (3) the law about the census. Nap's reference of this last law to the dispute between the censors is open to a further objection, which I need not here insist on, in that he includes in it the regulations as to municipal senates, obviously irrelevant to what he makes the essential aim of the law.

On Nap's view of matters military and politica the third lex Papia would seem to have had little effect. Its object was to exclude the Transpadani from the census, and this involved non-eligibility for service in the legions. Notwithstanding this, he infers from Bell. Civ. iii, 87 (quoted above) that Transpadani did serve in Caesar's legions. They could do this, he thinks, because Latins were not 'peregrini' but 'municipes.' But, if as 'municipes' they could join the legions without being on the census, why did their advocates in 65 take so much trouble to get them on the census? If we discard facts and evidence for theories and conjectures, we must expect disconcerting contradictions of this kind. On Latins as 'municipes' see below. 
party might well hope to secure two censors favourable to itself. It was desirable, too, to complete the 'lectio senatus' and if possible the whole census, while state contracts would be requiring renewal. Even if another dead-lock ensued, it would merely mean the status quo. At any rate, fresh censors entered office, and it seems to me impossible to doubt that they both belonged to the popular party. That they belonged to the same party is indicated by the fact that both equally were opposed by the tribunes, and that both resigned through the same apprehension of trouble to themselves; that they belonged to the popular party is shown by the Alien Act, unintelligible, unless some relief for the Transpadani was anticipated by the optimates. On this assumption, we can, I think, understand all that followed, the attack by tribunes, left by Nap without a motive, and the Alien Act, irrelevant on Nap's view to its context. There was still the possibility of an enfranchising law, and, if this could be rushed through, the popular leaders might even, with two friendly censors, get the new citizens enrolled in time for the elections in July. To meet this danger, the optimates took two steps, perhaps almost simultaneous. In the first place, they put up certain tribunes to block by their 'intercessio' the first censorial act, the 'lectio senatus.' If this was persisted in, there was no alternative but resignation, and the censors, fearing that resistance would be visited by an impeachment for ' perduellio,' or, as Dio less correctly puts it, by loss of senatorial rank, followed the example of their predecessors

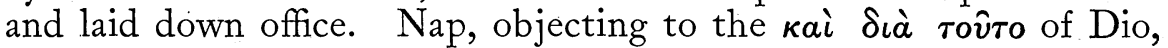
argues that they could not have resigned both on account of the tribunes' veto and of the Transpadane difficulty. I hope I have shown that the two causes were intimately connected. But at the same time, as a precaution and a manifesto, one of the tribunes, C. Papius, was instructed to pass an Alien Act, expelling from Rome any expectant beneficiaries of an enfranchising law who might happen to be in the city.

VII. THE ALIEN ACT OF PAPIUS.

Before dealing with the precise scope of this Alien Act, it is necessary to discuss Nap's representation of it. In the first place, as he insists that all his leges Papiae were passed on one and the same day, and as the whole raison d'être of his third law requires it to have been passed in 65 before the censors of 64 entered office, he is compelled to place the Alien Act in the interval between the two pairs of censors. If there were the slightest evidence for the third lex Papia, or for its object being what Nap assumes, there might be some reason for ignoring the order of events as implied by Dio, but an examination of the census clause on the Table of Heraclea 
has shown that there is none. But Dio, after describing the failure

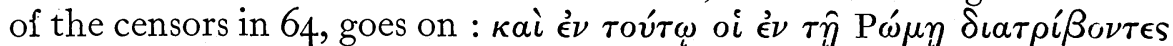
$\kappa . \tau . \lambda$. and the introductory words can only mean 'while this was going on,' i.e. in 64. But on Nap's view of the Alien Act, it really does not matter whether it was passed in 65 or 64 , or for that matter in 66 or $6_{3}$, for it has no relation to the Transpadane question, and there seems no reason why Papius should have passed it on the same day as his law excluding them from the census, or why Dio should have mentioned it in such close connexion with the two censorial failures. It is agreed that Dio's phrase oi $\epsilon^{\nu} \tau \hat{\eta} \mathrm{P} \omega \dot{\omega} \mu \eta$

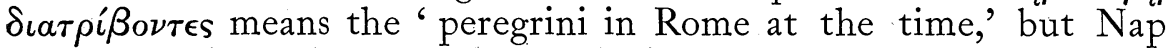
roundly declares that the Transpadani were not and could not have been expelled by the Act, because as Latins they were not ' peregrini' but 'municipes,' and as 'municipes' they had the legal right of residence in Rome. The last point needs evidence, but it is enough to say that this supposed right of residence did not prevent Latins being expelled under the two earlier Alien Acts of 126 and 95. The latter is described by Cicero (see below) as a law' de sociis et Latinis redigendis,' while the former provoked the revolt of Fregellae. But ' municipes,' as a class intermediate between 'peregrini' and full citizens, had long since passed out of existence ; and a 'municeps' was simply the citizen of a 'municipium.' If the 'municipium' was one of Roman citizens, as all in Italy now were, he was a Roman; if it was one with Latin rights, like Salpensa or Malaca, he was a Latin. Nor can it be maintained that Latins were not 'peregrini.' Latin colonies were after all simply the most favoured class of ' civitates foederatae.' 1 They were not usually called by this name, because their position was not due to a separate 'foedus' with Rome, but was a survival from the common ' foedus,' which had once bound together the members of the Latin League, the nucleus out of which the Italian confederacy had grown. But I should be content to let the point be determined in a simpler and more direct way. Latins, as we have seen, were affected by the two earlier Alien Acts, and yet the general object of both measures is given by Cicero as the expulsion of 'peregrini.' 'Male etiam qui peregrinos urbibus uti prohibent eosque exterminant, ut Pennus apud patres nostros.... Nam esse pro cive qui civis non sit rectum est non licere; quam legem tulerunt ... consules Crassus et Scaevola ; usu vero urbis prohibere peregrinos sane inhumanum est.' 2

But if the 'peregrini' expelled were not 'Transpadani, who were they? Nap's answer is that they were the foreigners of non-Italian extraction, especially the heterogeneous Greeks and Orientals who were residents or visitors in Rome, and who thronged or disturbed

\footnotetext{
1 That the Latin colonies fell under the class of 'civitates foederatae' in its widest sense is

indicated by Cicero's phrase 'Latinis, id est. foederatis' in pro Balb. 24,54 .

2 de Offic. iii, I I, 47 .
} 
the 'contiones.' 1 I can find only one point in favour of this view, and that is the reason suggested by Dio for the expulsion, namely, that they were persons regarded as too numerous and oủ $\dot{\epsilon} \pi \iota \tau \eta^{\prime} \delta \epsilon \iota \iota \iota$

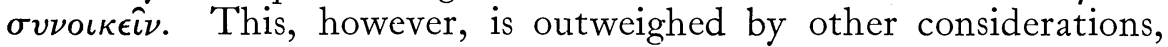
and merely suggests to my mind that Dio, while correctly giving from his authorities the scope and date of the measure, did not appreciate its exact relation to its context in his own narrative, and allowed himself a somewhat foolish conjecture. 'It is more important to determine the nature of the class exempted from the operation

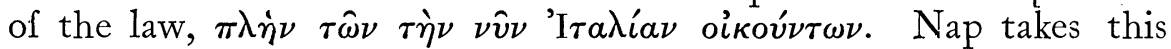
to mean 'except those who were natives of Italy and Cisalpine Gaul,' i.e. of Italy in Dio's own time. But why should Dio have brought in $\tau \grave{\eta} \nu ~ \nu \hat{v} \nu$ 'I $\tau a \lambda i ́ a \nu$ in this sense? The exempted class were of course ' peregrini,' and in Italy proper there were no nativeborn 'peregrini ' after the Social war. ${ }^{2}$ 'The only ' peregrini,' who in the wide sense were not of extra-Italian origin, were those in Cisalpine Gaul, and Dio could never thus have paraphrased his authorities' description of these. I believe that he did not paraphrase it at all, but that $\tau \grave{\eta} \nu \nu \hat{v} \nu$ 'I $\tau \alpha \lambda i a \nu$ is his rendering of their actual words.

But Nap is more interested in a more problematical class of exempted persons, of whom Dio gives no hint. He believes that within the ranks of Greek and Oriental foreigners a certain number could obtain exemption by making a declaration before a magistrate (professio) to the effect that they were teachers, or physicians, or professors of some liberal art. As a proof that there were exemptions, Nap cites de leg. agrar. i, 4, I3, where a Glaucippus 'illa lege qua peregrini Roma eiciuntur excipitur.' As an indication that physicians had to make a ' professio,' he adduces a passage of Suetonius, (Iul. 42) where Caesar presented with the citizenship 'medicinam Romae professos et liberalium artium doctores.' Finally, as confirmation of his hypothesis that these persons, if they claimed exemption, had to make a 'professio,' the first nineteen lines of the Table of Heraclea are declared to be the conclusion of, or a corollary to, the Papian Alien Act.

With regard to Glaucippus, Cicero's argument implies rather that he was a solitary exception than one of a class of exempted persons, and I think I can find room for him among Dio's exceptions. As to the 'professi medicinam,' they are of course not 'physicians who had registered,' but 'men who practised medicine.' Nor is there the smallest reason to identify the 'professi' of the Table of Heraclea with these supposed teachers, physicians and artists, who, according to Nap, were seeking exemption from the Alien Act.

1 pro Flac. 28, 66.

2 It would be perhaps cruel to press the point that on Nap's view neither were there any native- born 'peregrini' in the Cisalpine province, if the Transpadani were, as he contends, not 'peregrini.' 
On the other hand, there are two fatal reasons against it. Nap's applicants would ex bypothesi be 'peregrini'; the 'professi' of the Table were demonstrably Roman citizens. For (I) there is a strict prohibition against allowing them to benefit by the 'frumentationes,' a prohibition only intelligible in connexion with Roman citizens, since Greek and Oriental 'peregrini' had, as even Nap must admit, no claim whatever to receive corn. (2) It appears that women and minors (whom we should hardly expect to find among Nap's applicants) might make the required declaration through legal 'tutores,' a point which absolutely rules out Nap's hypothesis that these women and youths came under the category of extraItalian 'peregrini.'

But of course the possibility of an Alien Act such as Nap assumes does not necessarily stand or fall with this unhappy interpretation of the opening lines of the Table. It falls nevertheless from the total absence of evidence in its favour. Such an heroic measure as the expulsion of the foreign population of Rome was unique and unparalleled, and if actually carried, must inevitably have left some traces behind. Nap can point to none; he does not even attempt to show that the 'contiones' were less disorderly in the succeeding years, and he as utterly fails to explain why Papius should have practically tacked on this sweeping expulsion of foreigners to a law on the census of the Transpadani, as why he should have included in what was to all intents and purposes a 'lex satura' a parochial measure on repairing roadways and limiting traffic. I return to my own conception of the situation at the opening of 64 . There were two censors favourable to the popular policy, and if a law enfranchising the Transpadani could be hurried through, there might be a chance of enrolling them in the tribes and centuries in time to use their votes at the elections in July. But the optimates paralysed the censors and made their resignation inevitable by causing their first act, the ' lectio senatus,' to be blocked by tribunician 'intercessio.' Under the circumstances the idea of an enfranchising law, which could no longer affect immediate issues, was given up, and has left no trace, except as explaining the quarrel between the censors of 65 , and throwing light upon the second move of the optimates, the Alien Act of Papius. There is indeed an extraordinary, and surely not accidental, parallel between the circumstances of $65-64$ and those of $\mathbf{I} 26$ and 95 . In the first year there was known to be impending, with a view to ease the agrarian situation, the proposal of Fulvius Flaccus, actually made next year, to grant the 'civitas' to the Italians, i.e. to the Latin and federate towns. In 95 there was violent agitation among the Italians, and many of them 'summa cupiditate Romanae civitatis' illegally anticipated the exercise of full civic rights. ${ }^{1}$ In

${ }^{1}$ Ascon. in Cornelian. 67. 
65 , as a sequel to local agitation for the franchise among the Latin colonies, we find violent dissensions in Rome, reflected in the attitude

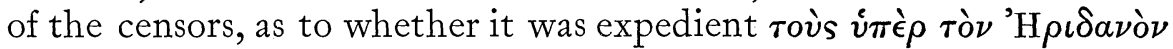

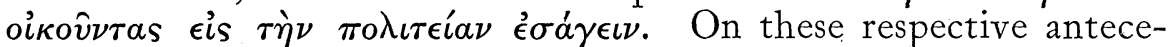
dents what followed ? In the first case a tribune, Iunius Pennus, passed an Alien Act, by which ' peregrini,' no doubt limited by some excepting clause to those expecting enfranchisement, were expelled from Rome. ${ }^{1}$ In the second case the lex Licinia-Mucia was passed, a more complicated measure, for it had to deal with actual usurpation of citizen rights, but in part an Alien Act, expelling 'socii et Latini' from Rome. ${ }^{2}$ In precisely the same way, if we believe Dio and Cicero, ${ }^{3}$ an Alien Act was passed on the occasion we are considering, expelling 'peregrini' from Rome. Can we avoid the conclusion that the expelled 'peregrini' were in this case too some of those about whose admission to the 'civitas' parties were divided ?

But does Dio's description and specification of the persons expelled tally with this view? They were oi év $\tau \hat{\eta}{ }^{~ '} \mathrm{P} \omega \mu \eta \eta$

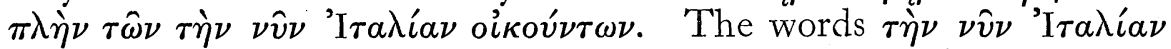
are the only difficulty, and I have already argued against the supposition that Dio uses them from his own point of view. It is far more likely that the excepting clause is taken straight from the authority, and is the historian's rendering of what he found. I take the exempting clause to be: "with the exception of any "peregrini " now in Rome, who have a domicile in Italy, as now determined.' Considering that the boundary of Italy had been altered not more than sixteen or seventeen years earlier, this careful precision is what we should expect in a law of the kind; it would e.g. safeguard the position of 'peregrini' domiciled in Ariminum. But this interpretation of the clause represents as the exempted persons exactly the class which, on Nap's view, was expelled. For the only 'peregrini' domiciled in Italy at this time were foreigners of non-Italian origin, and all of these, whether domiciled in Rome itself, or visiting Rome from other domiciles, were unaffected by the Papian law. On the other hand, any 'peregrini' domiciled outside Italy, and therefore any Transpadani from the Latin colonies in the Cisalpine, who happened to be in Rome, would have to leave.

Of course, such an Alien Act could not by itself prevent the passing of an enfranchising law. The Act of Pennus did not prevent the proposal next year of Fulvius Flaccus, though it may have done something towards its defeat. Similarly, the lex Licinia-Mucia did not hinder Livius Drusus from taking up the cause of the Italians, and

1 de Off. iii, $\mathrm{xI}, 47$.

${ }^{2} \mathrm{It}$ is this double character of the law which explains Cicero's mixture of praise and blame. As dealing with usurped rights he approves it; as an Alien Act he condemns it. He says in pro Sest. I3, 30, 'nihil acerbius socii et Latini ferre soliti sunt quam se, id quod perraro accidit ex, urbe exire a consulibus iuberi.' The reference' according to Schol-Bob, is to the law of 95 , by which it was enacted: "ut redire socii et Latini in suas civitates iuberentur.'

3 de leg. agr. $\mathrm{i}, 4, \mathrm{r} 3$. 
perhaps did more to intensify than to dissipate the agitation. Still, the lex Papia, especially coming after the action of the tribunes, might have considerable moral effect, would serve as an optimatist manifesto, and if, as is probable, a good many Transpadani had been attracted to Rome, it might put a practical stop to much intrigue and agitation.

It remains to notice two individual sojourners in Rome, whose treatment under the lex Papia differed as much as that of the chief butler and of the chief baker. Cicero ${ }^{1}$ speaks of a Glaucippus whose exemption from the Alien Act was as marked as Pompey's exemption from the requirement to hand in 'manubiae.' Nap regards him as one of a class of registered exempts, whereby the point of comparison with Pompey is lost. I take him to be a foreigner domiciled in some Transpadane town, whose presence in Rome therefore brought him under the Papian Act, but who, not coming under its intention, had received special exemption. On the other hand, in the year $5 \mathrm{I}$ a citizen of Novum Comum found himself in Rome just at the time when the government had legally or illegally declared the town to be a Latin and not a Roman colony. Marcellus, on some pretext not specified by the historians, seized this man and had him publicly scourged, as a practical demonstration that he was not a Roman citizen. I suggest that the consul may have used as a pretext for his action the Alien Act of Papius which, however ephemeral its immediate object, may nevertheless have remained on the statute book, a trap for unwary Transpadani.

\footnotetext{
1 de leg. agr. i, 4, I3.
} 